\title{
Monetary Economic Research at the St. Louis Fed During Ted Balbach's Tenure as Research Director
}

\author{
Michael D. Bordo and Anna J. Schwartz
}

\begin{abstract}
Ted Balbach served as research director at the Federal Reserve Bank of St. Louis from 1975 to 1992. This paper lauds his contributions during that time, including the expanded influence of the Review, enhanced databases and data publications, and a visiting scholar program that attracted leading economists from around the world. Balbach is remembered fondly as a visionary leader and gracious mentor.
\end{abstract}

Federal Reserve Bank of St. Louis Review, September/October 2008, 90(5), pp. 499-504.

\section{BACKGROUND}

 he monetarist movement took shape in the 1960s. The name gained usage and became trite. Basically, its adherents believed in the quantity theory of money, but in 1968 Karl Brunner named them monetarists. In today's terminology, the movement would be viewed as a network of young economists who shared the belief that the quantity of money was an important variable with explanatory power for the price level and cyclical fluctuations in economic activity. ${ }^{1}$

Graduate students in economics became members of a club that had two branches. One consisted of students of Brunner at UCLA. Ted Balbach was a member of this branch. The other branch centered on students of Milton Friedman, particularly members of the Money Workshop at

1 Other elements of monetarism included (i) the view that inflation was everywhere and always a monetary phenomenon; (ii) that the Phillips curve was vertical; (iii) the importance of monetary rules, such as Friedman's constant monetary growth rule, instead of discretion; (iv) a critique of fine tuning; and (v) the dominance of monetary over fiscal policy (Friedman, 1960, 1968; Brunner, 1968; and Stein, 1976). the University of Chicago and also some who worked on the money and business cycle project at the New York headquarters of the National Bureau of Economic Research.

The two branches shared a common interest in two organizations that bridged their separate memberships. One was the Shadow Open Market Committee (SOMC), formed in 1973 under the aegis of Brunner and Allan Meltzer to advocate improved monetary policy, particularly urging the Fed to act decisively to reduce inflation, which had been accelerating since 1965 absent persistent action to tighten. Members of the SOMC, presumably individuals with monetarist leanings, came from wider backgrounds than those of the two branches. The other organization that bridged the membership of the two branches was the Federal Reserve Bank of St. Louis, which was distinguished as the first bank in the System to be headed by a president who expressed monetarist views and that had a research program (headed by Homer Jones) that featured topics of importance to monetarists. After he retired as research director of the St. Louis Fed, Jones joined the SOMC.

Michael D. Bordo is a professor of economics at Rutgers University and a research associate at the National Bureau of Economic Research. Anna J. Schwartz is a research associate at the National Bureau of Economic Research. The authors thank Jerry Jordan and others who commented on the paper when it was delivered at a conference held by the Federal Reserve Bank of St. Louis on March 3, 2008, in honor of Ted Balbach. Michael Bordo met Ted Balbach in 1981 when he was a visiting scholar at the St. Louis Fed. He remained good friends with him until his passing in December 2007. Anna Schwartz knew Ted well since the 1970s through the monetarist network.

(C) 2008, The Federal Reserve Bank of St. Louis. The views expressed in this article are those of the author(s) and do not necessarily reflect the views of the Federal Reserve System, the Board of Governors, or the regional Federal Reserve Banks. Articles may be reprinted, reproduced, published, distributed, displayed, and transmitted in their entirety if copyright notice, author name(s), and full citation are included. Abstracts, synopses, and other derivative works may be made only with prior written permission of the Federal Reserve Bank of St. Louis. 
One example of the links between Ted at the St. Louis Fed and the SOMC is that the St. Louis commercial bank that employed Ted's wife, Rachel, paid the expenses for her semiannual trip to New York to attend SOMC meetings and report the issues that had been discussed.

We have now set the stage for Ted Balbach's appointment as the St. Louis Fed director of research in 1975. The backdrop was the struggle by leaders of the monetarist movement to uphold propositions about the relation between money and economic variables such as income, prices, and interest rates that Keynesians of that time and earlier denied. Mainstream views (especially in the Federal Reserve System) were predominantly those of Keynesians.

In the period before 1975, research activities at St. Louis had a significant influence on the debates between monetarists and Keynesians. It was exciting for monetarists to score a victory by a St. Louis research product proving a point over a contrary Keynesian position. One such episode occurred in the dispute about the importance of fiscal policy versus monetary policy for economic stabilization. The Keynesian stand was that both mattered. The monetarist position was that only money mattered. The 1968 St. Louis Fed study by Leonall Andersen and Jerry Jordan provided strong support for the monetarist position. According to their data, the response of economic activity from 1952 to 1968 was larger, more predictable, and faster for money than for the fiscal variables of budget cuts or tax changes. The result brought joy to the monetarist camp, although Keynesians were unimpressed by a single-equation triumphonly the result of a multi-equation general equilibrium model could provide credible evidence.

By the time Ted Balbach began managing research, the conflict with Keynesians had lost some of its adversarial ardor in the academic world (although perhaps less so in the Fed). And by the 1980s the Keynesian approach began to shift, becoming more inclusive of monetarist views, especially with regard to inflation as fundamentally a monetary phenomenon. Thereafter, research at St. Louis could concentrate on scholarly issues unrelated to the divisiveness of the earlier conflict.

\section{RESEARCH AT THE ST. LOUIS FED}

\section{7 to 1975}

Ted Balbach extended the research program begun by Homer Jones. Leonall Andersen and Jerry Jordan served as research directors between Homer's retirement in 1972 and Ted's appointment in 1975. The chief accomplishments in this period were these: First, the Federal Reserve Bank of St. Louis Review developed into a major publication that influenced policymakers and economists in the Fed and other central banks and led notable academics to write for it (see the names listed in the next subsection). Second, a special feature of the Review was the attention paid to measurement of the monetary base and other aggregates and also to problems created by System policies, such as lagged reserve requirements for member banks. Data series on monetary aggregates and other variables became essential for serious research on money and the macroeconomy. Third, establishment of a visiting scholars program exposed the bank staff to and allowed them to be influenced by ideas from academia and other central banks and also spread the message of the St. Louis Fed to a wider audience.

The Review. The Review contained articles on various aspects of monetary economics: monetary policy, money stock determinants, the transmission mechanism, international money, the demand for money, inflation, gold and the balance of payments, monetarism, and monetary versus fiscal policy. The key authors in this period were research staff members: Leonall Andersen, Norm Bowsher, Albert Burger, Keith Carlson, Alton Gilbert, Jerry Jordan, Dennis Karnosky, Michael Keran, Cliff Luttrell, Charlotte Ruebling, Roger Spencer, James Turley, and Ted Balbach.

In addition to articles written by the research staff, several important articles were contributed by scholars in the monetarist camp, including Karl Brunner, David Fand, Milton Friedman, Phil Gramm, Harry Johnson, James Meigs, Allan Meltzer, and Bob Rasche; other important scholars also wrote for the Review, giving it a broader coverage. These included Gerry Dwyer, William Gibson, Patric Hendershott, Lawrence Klein, John 
Pippenger, Ronald Teigen, Murray Weidenbaum, and William Yohe. The views of senior Fed officials, including Andrew Brimmer, Arthur Burns, Darryl Francis, and Robert Solomon, appeared in various issues.

Data. The public distribution of financial data began on Homer Jones's watch. He first developed the weekly U.S. Financial Data, which showed the levels of selected monetary aggregates and their growth rates over various ranges (the famous triangles) as well as other financial data. Jones then started the monthly Monetary Trends and National Economic Trends publications. The data therein were widely used by the public and within the Federal Reserve System for policy analysis (Poole, 2006).

Visiting Scholars. A visiting scholars program was introduced in the few years before 1975 . Many leading academics in the monetarist camp visited the Bank, lectured, and, as noted above, published articles in the Review. These included Karl Brunner, Milton Friedman, and Allan Meltzer. A number of scholars from Germany also visited the Bank in these years, including Wolfgang Schmitz, Dieter Hoffman, and Manfred Willms. Scholars from Mexico, Spain, and England also visited. This program preceded the future development of formal links to the hard currency central banks of Switzerland and Austria.

\section{5 to 1992: Ted Balbach's Term}

On Ted's watch all aspects of the program inherited from Homer Jones were greatly expanded, and he added a number of programs of his own design.

The Review. The scope of the Review broadened greatly under Ted's tutelage. The key monetarist themes remained and were extended. Articles investigated the money supply, money demand, monetarism, inflation, the transmission mechanism of monetary policy, international money, and the balance of payments and exchange rates. These article explored new subjects reflecting changes in the United States and global economies and discoveries of monetary and macroeconomic research. These included fiscal deficits, real interest rates, energy, supply shocks, productivity, economic growth, financial markets, financial innovation, forward exchange markets, real exchange rates, bank failures, rational expectations, tax reform, protectionism, payments system risk, the gold standard, Bretton Woods, and globalization.

Reflecting an expansion of the Research Department, the list of research staff authors expanded. Among new authors were Rae Balbach, Dallas Batten, Michael Belongia, Donald Brown, James Bullard, Alison Butler, Claudia Campbell, Cletus Coughlin, Michael Dueker, Michelle Garfinkel, Rik Hafer, Scott Hein, Steve Holland, Nancy Jianakopolos, Donald Kemp, Kevin Kliesen, Richard Lang, Douglas Mudd, Christopher Neely, Philip Nuetzel, Mack Ott, Michael Pakko, David Resler, Steve Russell, Gary Santoni, Neil Stevens, Courtenay Stone, Jack Tatom, Daniel Thornton, Michael Trebing, Jai-Hoon Yang, and Adam Zaretsky.

Leading academics also contributed important articles, many of them delivered as the Homer Jones Memorial Lecture, a series inaugurated by Ted in 1987. Among the lecturers were Karl Brunner, David Laidler, Allan Meltzer, Anna Schwartz, and Beryl Sprinkel. Many visiting scholars (see Table 1) contributed Review articles on diverse subjects.

The Review, which was widely and freely disseminated around the world, influenced readers behind the Iron Curtain in the 1970s. According to Jerry Jordan, Václav Havel cited the importance of the Review, because it was free and uncensored, in influencing the development of his free-market views hence contributing to the Velvet Revolution in Czechoslovakia.

Ted started the Annual Economic Policy Conference in 1976. This annual series of conferences brought leading economists from around the United States and world to discuss pressing topics of the day in economic policy. The seventeen conference subjects selected during Ted's tenure had such titles as Financing Economic Growth: The Problems of Capital Formation; Stabilization Policies; The Supply-Side Effects of Economic Policy; The Monetary versus Fiscal Policy Debate; and How Open Is the U.S. Economy? Many of the conferences were published in the 


\section{Table 1}

\section{Visiting Scholars During Ted Balbach's Tenure}

Byung Chan Ahn, Bank of Korea

Rachel Balbach, Boatman's Bank

Peter Bofinger, Landeszentralbank, Baden-Württemberg

Michael D. Bordo, University of South Carolina;

Rutgers University

K. Alec Chrystal, City University of London

Alex Cukierman, Tel Aviv University

Lawrence S. Davidson, Indiana University

José Luis De Molina, Banco de España

Kevin Dowd, University of Nottingham

Dean S. Dutton, Brigham Young University

Gerald P. Dwyer Jr., Clemson University

Salam K. Fayyad, Yarmouk University (current Prime Minister of the Palestinian Authority)

Steven M. Fazzari, Washington University in St. Louis

Robert Fluri, Swiss National Bank

Joel Fried, University of Western Ontario

Werner Hermann, Swiss National Bank

Donald Hooks, University of Alabama

George Hubmer, Austrian National Bank

Dennis W. Jansen, Texas A\&M University

John W. Keating, Washington University in St. Louis

Byun Ki-Sook, Bank of Korea

Levis A. Kochin, University of Washington

Kees G. Koedijk, Erasmus University Rotterdam;

Maastricht University

Clemens J.M. Kool, Erasmus University Rotterdam;

Maastricht University; Utrecht University
Fernando Méndez Ibisate, Universidad Complutense de Madrid

Laurence H. Meyer, Washington University in St. Louis

Dewet Moser, Swiss National Bank

Manfred J.M. Neumann, University of Bonn

Seonghwan Oh, University of California-Los Angeles

Sanghyun Park, Federal Reserve Bank of New York

Alex Pollock, American Enterprise Institute for Public Policy Research

Dieter Proske, Austrian National Bank

Carlos Quiroz, Banco Central do Brasil

Robert H. Rasche, Michigan State University

Ronald A. Ratti, University of Missouri-Columbia

Tobias Rötheli, Swiss National Bank

Zalman F. Shiffer, Bank of Israel

Courtenay C. Stone, California State UniversityNorthridge

Philip Stork, Maastricht University

Paul T.W.M. Veugelers, Erasmus University Rotterdam Jürgen von Hagen, University of Bonn

Patrick J. Welch, Saint Louis University

David C. Wheelock, University of Texas, Austin

Geoffrey Wood, City University of London

Piyu Yue, University of Texas

Mathias Zurlinden, Swiss National Bank
Review, a few in a book series by Kluwer. The authors included such luminaries as Alan Blinder, Richard Cooper, Jacob Frenkel, Ben Friedman, Ben McCallum, Rick Mishkin, Bill Poole, Larry Summers, and John Taylor.

Data. Under Ted, databases and data publications were expanded. He started International Economic Trends in 1978 and the St. Louis Fed's online database FRED (Federal Reserve Economic Data) in 1991. The latter has been greatly expanded over the years and is very widely used.
Visiting Scholar Program. The visiting scholar program burgeoned under Ted. Over 40 scholars from around the world were numbered among the visitors to the Bank. (See Table 1.) Most stayed at the Bank for six months to a year, interacting with the staff and writing articles for the Review.

Other Activities. As noted, Ted designed annual policy conferences beginning in 1976, in collaboration with the Center for American Business and Enterprise at Washington University. 
He also instituted the annual Homer Jones Memorial Lecture Series mentioned earlier, with the support of local universities and the local National Association for Business Economics.

Ted also engaged in considerable outreach activities with other "monetarist" central banks. He started a formal exchange program with the Swiss and Austrian national central banks as well as an ongoing informal collaboration with the Bundesbank and the Bank of England. Numerous researchers from these central banks came to St. Louis. In return, a number of the Bank's staff economists were sent to various central banks for extended visits.

Ted usually attended the Konstanz (started in 1970) and Carnegie Rochester (started in 1973) conferences. Sometimes he delegated other researchers to attend these conferences. Ted also sent staff economists to New York and Washington to get firsthand knowledge about how the Open Market Desk worked and to interact with people at the Board. Some of the senior staff were allowed to attend Federal Open Market Committee meetings.

\section{Other Contributions by Ted Balbach ${ }^{2}$}

Ted contributed to research at St. Louis in a number of intangible ways and strengthened its position as the premier Research Department of the Reserve Banks of the Federal Reserve System. He was an excellent mentor to the staff and visiting scholars. His role was to encourage research and prod people to do it better in a timely manner. His most important and persistent demand from researchers was presentation and tests of hypotheses with clarity and simplification. He stressed the importance of communication, especially to policymakers and financial market participants. Ted read and commented on every article published in the Review.

\section{CONCLUSION}

The present status of the Review is a tribute to Ted's vision of what it could become. All in all,

2 For help with this and the preceding section, we thank Jack Tatom, Dave Wheelock, and Bob Rasche. while Balbach was in charge, the Review was a stimulating publication. It is fitting that we honor him for his service.

Ted was the counselor to four presidents of the Federal Reserve Bank of St. Louis (Francis, Roos, Roberts, and Melzer), the latter three having little monetary policy background. He inspired the presidents he served to uphold the principles of price stability and, toward this objective, the control of monetary aggregates. ${ }^{3}$ In the era of the Great Inflation and its aftermath, his defense of these principles was not the standard view it has become since.

In the debriefings to the staff after FOMC meetings that Ted attended, he reviewed the discussion in detail. According to those present, he had an excellent and often very humorous grasp on the issues, including the dynamics of the discussion and the inconsistencies in the remarks and votes of the participants.

Ted was a networker par excellence. He knew everybody and everything that was going on in the world of monetarism and monetary policy in the United States and Europe. He facilitated useful communication in the profession. Were he of this generation, he would be an avid user of Facebook and YouTube.

\section{REFERENCES}

Anderson, Leonall and Jordan, Jerry. "The Monetary Base-Explanation and Analytical Use." Federal Reserve Bank of St. Louis Review, August 1968, 50(8), pp. 7-11.

Brunner, Karl. "The Role of Money and Monetary Policy." Federal Reserve Bank of St. Louis Review, July 1968, 50(7), pp. 9-24.

Friedman, Milton. A Program for Monetary Stability. New York: Fordham University Press, 1960.

3 According to Jerry Jordan, the Board of Governors brought these men (who had no prior monetarist leanings) to St. Louis in an attempt to counteract its monetarist orientation. Ted, according to Jordan, instructed them well and convinced them of the importance of "sound money." 


\section{Bordo and Schwartz}

Friedman, Milton. "The Role of Monetary Policy." American Economic Review, March 1968, 58(1), pp. 1-17.

Poole, William. "Data, Data and Yet More Data." Federal Reserve Bank of St. Louis Review, March/ April 2007, 89(2), pp. 85-89.

Stein, Jerome L., ed. Monetarism. Amsterdam: North Holland, 1976. 